\title{
9. 'The innocence in her beautiful green eyes': Speculations on seduction and the 'feminine' in the Australian news media
}

\begin{abstract}
It is a familiar refrain to describe journalism as, simply, story-telling (Manoff, 1986). The aim of this article, however, is to explore how that simple project turns complicated in a place like Australia, with its lingering anxieties of culture and identity (Gelder \& Jacobs, 1998, p.142). This article is a start to a longer study of the specific critical and cultural implications of contemporary journalism, practised in an 'unsettled' Australian postcolonial milieu. Here, the study makes some speculative observations of gender representation in long-running news stories about two women: Schapelle Corby and Lindy Chamberlain. My disciplinary background is cultural studies, not social sciences. ${ }^{1}$ The result here, therefore, is not a set of conclusions drawn from content analysis as would be the case in a different kind of paper. I also want to lend support to the discussion in journalism scholarship of the conundrum of 'objectivity' for journalistic practice in socio-political contexts where assumptions of 'objectivity’ may, in fact, obscure journalism's public interest principle.
\end{abstract}

JANINE LITTLE

University of Southern Queensland

Everything is seduction and nothing but seduction. They wanted us to believe that everything was production. (Jean Baudrillard, On Seduction). ${ }^{2}$

$\mathrm{W}$

HEN I first devised this article, I envisaged also discussing more, relatively recent, 'big stories' about women: the Natasha Ryan, 'girl in the cupboard' case of 2003, and, more recently, model

PACIFIC JOURNALISM REVIEW 12 (1) 2006131 


\section{CONTEMPORARY GENDER ISSUES}

Michelle Leslie, caught in Bali with two ecstasy tablets; and Renae Lawrence, the Bali Nine drug 'mule' serving her sentence alongside Schapelle Corby in a Denpassar jail. Schapelle and Lindy are enough, even excessive, however, in what they tell us about news media coverage and its links to more slippery contests of power, and appearance, in Australia. Perhaps it would be useful to illustrate the obvious: how Schapelle and Michelle's looks meant their generally sympathetic portrayal as subjects worthy of media space, and home space. It is more useful, though, to ask why the story gets more complicated with Lindy Chamberlain, and how speculation on that question might make other similar, recent Australian news stories - of the hanging in Singapore of drug trafficker Tuong Van Nuygen, the Bali Nine, the Cronulla riots - comprehensible as part of the broader, national 'unsettling' described earlier.

In terms of journalism's reproduction of the markers of exclusion and stereotype, feminist scholars such as Catharine Lumby (1997), Lisa McLaughlin (1998) and Ann Curthoys (2000) have already laid foundations for a study specific to journalism scholarship that might go beyond stock answers. Following their work, the task here is to push back a reflexive treatment of all those newspaper photographs and (tele)vision of Schapelle Corby's attractive, anguished face behind prison bars. Emphasis is placed, instead, back home (in Australia). That is where free-floating anxieties of threat mix with more focused aspirations to gain, produce, and guard nationally sacred spaces of individual, family, and lifestyle. Because of this cultural trend, Schapelle's 'beautiful green eyes' gesture toward an observation of how stereotypes of femininity and innocence are activated in stories about women. More importantly, though, her story shows how journalistic recourse to the familiar, the acceptable, the 'Australian', can never account completely for the anxieties working beyond the production and reproduction of particular feminine subjects. It supports what James Fallows (Martinson, 2006, p. 13) sees as 'the real purpose of journalism ... to satisfy the general desire for information to have meaning'. David Martinson (ibid) specifies this sense of purpose as observable in ' ... journalists who recognise a serious obligation to move beyond functioning as the equivalent of an office stenographer for those in positions of power'.

Part 1: The unsettling feminine

Considered next to the earlier representation of Lindy Chamberlain, 132 PACIFIC JOURNALISM REVIEW 12 (1) 2006 
Schapelle's story brings an opportunity to observe how feminine subjectivity works in contemporary news media representation as the privileging of masculine apprehensions of identity and power. This privileging is described by Baudrillard as part of the domination of production in later Western capitalist societies, and its attendant structures of meaning. These structures generate 'the impulse towards creating distinctions, towards the definition of things, in contrast to the feminine as seductive, as the impulse that puts this very definition into question, dissolving the terms of the opposition' (Grace, 2000, p. 151). ${ }^{3}$ It is well documented, in postcolonial studies, for example, how masculine privilege shaped the Australian colonising moment (Gelder \& Jacobs, 1998, Dixson 1999, Curthoys 2000, Summers 1975). Through Baudrillard's observation of the seductive impulse, it is possible to comprehend how contemporary media representations render that colonising moment, that historical context for privilege (and forgetting) mostly imperceptible. Australians trying to make meaning, for themselves, out of journalistic coverage of women subjects, do not need to draw on a set of explicit signs. Seduction, according to Baudrillard, is 'about the annulment of signs, their reversion, and the transformation of their meaning into "pure appearance" (Grace, 2000, p.143). ${ }^{4}$ The slippage making it possible to speculate on what 'big' stories about women can reveal about Australian anxieties of identity and belonging occurs when appearances activate those older registers of nationalistic unsettlement: registers that rely upon ambivalent representations of women as at once victims, and threats.

Television, newspapers and magazines loved Schapelle, and picked up on what was encapsulated in a comment by one of the story-watchers at home, in Australia, that he could just see 'the innocence in her beautiful, green eyes'. I chose this single marker of meaning from a stream of similar protestations of innocence by, and on behalf of, Schapelle, recorded on various newspaper and TV websites and blogs (NineMSN Corby Trial). The story is now so folkloric that we just call it Schapelle. Seeing 'the innocence in her beautiful green eyes' means, at the level of consumption Lumby (1997, pp.120-29) describes in her work on tabloidisation and the public-private domain, not seeing complications implicit in discussions of gendered representations of justice in journalism. It is as if, at the level of production, the story just gets told in an uncomplicated way, as the story, as Graham Seal notes, of a 'damsel' who is 'one of us' (Seal, 2005).

Chiming into the news media's telling of the story though, are some espe- 


\section{CONTEMPORARY GENDER ISSUES}

cially significant key notes in Australia's historic negotiation of female, and 'feminine' subjectivity. Telling the story as a travesty of justice, a spectacular misfortune suffered by our 'victim' masks, as stated, mostly imperceptible anxieties about national security and individual identity. Ann Curthoys (2000, p.14) sees the representational 'contest over the past' in Australia as one that 'place(s) white Australians as victims struggling heroically against adversity' against material instances of their aggression, 'bringing adversity upon oth-

ers'. It links interestingly to Graham Seal's (2005) point about lingering prejudice against the Indonesian justice system, when Curthoys (2000, p. 13) observes that non-indigenous Australians also have 'difficulty seeing themselves as beneficiaries of the colonisation process'.

Journalists, perhaps, are hard-pressed to think about these histories when they put stories together, but their aspiration toward objectivity would certainly be more consistent with such thought than a reproduction of stereotypical signs and subjects. According to Seal (2005), Schapelle struck a social chord that was not of an objective sense of justice, but a '.. a powerful folk belief, a prejudice against the Indonesian justice system held by many Australians'. This is why the critical point would be missed by focusing on Schapelle's cosmetic appearance and analysing content to prove the fairly easy point about representational patterns in news. Schapelle was a seductive story because it coaxed out prejudices and fears of a nation convincing itself that it is innocent, that its sacredly held myths of fortune, security and freedom mean as much outside its borders as inside. The discussion of journalistic objectivity and of journalism as a practice (at least in principle) with a democratic role of serving the public interest, reproductions of feminine subjects like Schapelle and Lindy direct critical work into a recuperation of a materialist engagement with Australia's actual past instead of just its memories. Further critical work, for instance, could include attention to what Ken Goodwin (2005) describes as the need for an epistemological account of the limitations of communication theory, via 'some form of materialism'.

\section{Part 2: The story objective-a seductive amnesia}

The critical direction above connects with Baudrillard's observation of a baseless, illusory equation of the productive with masculinity should again be emphasised as an equation he casts as dependent on historical context. Making critical inroads into how women fare in stories such as Schapelle and Lindy must involve, therefore, some account of Australia's unsettled colonial 134 PACIFIC JOURNALISM REVIEW 12 (1) 2006 
past. It is also important to undertake this account as a way of establishing a critical base to read the cluster of identity motifs described earlier, and activated in stories like the Cronulla, Macquarie Fields and Palm Island riots. This means we cannot 'read' news stories in Australia without accounting for some dissonance between journalism as an at least aspiring objective social practice, and the stories which draw upon deeply entrenched ideological constructions of femininity and justice.

Masculine privilege operates in stories like Schapelle and Lindy by relying upon prior understandings of victimhood, threat, and nationality, but this is never represented explicitly. Women and men are equal, in Australian comprehension, before the law. Feminist critic Ewa Ziarek (2005, p. 92 ) argues it is precisely this denial of any 'outside' (or excess, as mentioned earlier) to the principle of capitalist exchange based on equivalence' that reinforces hegemonic discourses of oppression on the basis of gender, race, ethnicity and other markers of identity. This may be a useful theoretical key change for journalism scholarship informed by feminist theory. Australian news media products could be considered on the same terms as their interpretation by audiences; just over half of whom, according to a Morgan poll, believed Schapelle was innocent. According to Morgan (2005), though:

The trial and sentencing of Schapelle Corby has received a great deal of media coverage. The media would have everyone believe that an overwhelming majority of Australians think Schapelle Corby is innocent, however this latest Morgan poll shows only a slight majority (51 percent) believe Schapelle Corby is innocent while 21 percent believe she is guilty. There are 28 percent of Australians undecided on whether she is guilty or not.

This was a statistical challenge to the perceived role of 'the media' in the construction of Schapelle's innocence. At surface level, the Schapelle story grew big by virtue of sheer news value, in a kind of seductive amnesia. It was as if there was no back story, not so much as an unnerving Indonesian neighbour with whom Australia had had its moments, or scenes at home of a government returned to office on the strength of its dealings with asylum-seekers stranded off our northern shore (Marr and Wilkinson, 2003, Manne, 2006). Robert Manne (2006, p. 22) states that the 2001 'Tampa Crisis' transformed Australian politics and ensued the current climate of 'economic rationalism 


\section{CONTEMPORARY GENDER ISSUES}

and populist conservatism' devoid of older liberal 'humanitarian considerations' and, according to Marr and Wilkinson, characterised by the relief accorded mainstream Australia from having to negotiate with its conscience. Under economic rationalism and popular conservatism, everyone is equal. Yet, as McLaughlin (1998, p. 83) argues in relation to the O.J. Simpson trial in the United States, such an 'objectivist epistemology' is 'threatened by the revelation that it can only work effectively by hiding its differences'.

It is useful to speculate on how this epistemological friction is traceable in Australian journalism's stories of Schapelle and Lindy. Relating back to my earlier argument about the unsettled nature of Australian culture and identity, McLaughlin's observation that the O. J. Simpson case caused so much 'discomfiture' in the American context because it involved 'an exposure of the US's existing tendencies toward racism, misogyny and celebrity worship' is enabling. It assists with a turning of focus, in feminist critique of news stories about women in Australia, to the historical context that Baudrillard observes as the font of illusory masculine-feminine divisions. 'The nation', McLaughlin argues, was 'humiliated by having been caught with its differences showing in public' (ibid.). I have argued elsewhere (Little, 1998, 1999) how the spectacular fall of O.J. Simpson from the celebrity accorded him through sport, a high media profile and Hollywood bit-parts also involved a crash from success imbued with the symbolism of 'honorary whiteness'.

It was a success accorded on terms: terms rescinded, as McLaughlin (1998, p. 79) notes, with an audience engaged in 'forensic spectacle', a 'public sphere of production' in the Habermasian sense, 'deriv(ing) force directly from capitalist production'. McLaughlin cites Habermas's location of such a public airing of matters in the dominant ideological operations of consumer capitalism, where they are 'private' - as in family matters and domestic violencebut do not assume a transformative political dimension via the media spectacle. The public debate, the audience participation in the story, is instead complicit with the media's production of it.

For the feminist critical insistence that 'the personal is political', maintenance of the division between this Habermasian public sphere (where stories like O.J. and Schapelle are disseminated), and the private space of audiences and subjects (making sense of their world, their own epistemological sense of identity, nation and values) is illusory. Journalism's material sense of history is grounded in a principle of public interest yet practised in an historical context. This is why the Baudrillarian observation of seduction as defying the

136 PACIFIC JOURNALISM REVIEW 12 (1) 2006 
notion that everything can be communicated by mere representation is so useful for reading stories like Schapelle and Lindy. Applying this feminist theoretical approach to journalism about women, in postcolonial contexts, allows for more comprehensive explanations for story construction than those which merely acknowledge reproduced hegemonies of form and content. It picks up on the seductive play of a whole range of cultural anxieties, working against privileged masculinity in private, and sacred, Australian space.

\section{Part 3: Boogie board and the baby-the Australian sacred}

A clearer view of my argument is possible with a consideration of an object associated with Schapelle, from the time of her arrest at Denpasar airport. The arrest was the moment of connection between the private woman, and the public crime. An object enabled that connection, and led to what Channel Nine called 'Schapelle's Nightmare': her boogie board. Read at face value, the object caused the friction between the Morgan Poll results released not quite a month after Schapelle was sentenced to 20 years jail, and news media representations of an innocent, beautiful, yet hapless young Australian woman caught up in the harsh legal realities of a neighbouring country always in tenuous relationship with 'us'. Yet, the boogie board in this story leads into other myths of home and lifestyle activated in that seductive connotation of an object owned for sheer enjoyment.

The boogie board symbolises stereotypical Australian notions of leisure, fun, a long-held habit Australians have of gravitating to coastal beaches, away from the threats and harshness of a dry interior. For Schapelle, and hundreds of Australians like her, the boogie board was checked-in baggage for a Bali holiday. The only problem was that this one contained a $4 \mathrm{~kg}$ bag of marijuana: enough to attract a drug trafficking charge under Indonesian law. No one knew how it got there. Some blamed baggage handlers. An enterprising few started charging $\$ 8$ a pop to shrink-wrap baggage for departing passengers at Australian international airports. Consider this in the admixture of the Bali Bombing, in which more than 200 people were killed in bomb blasts at bars known for their popularity with Australian tourists; a mounting national anxiety at the 'terrorist threat' against Australia stirred after the Iraq invasion; the Al-Quaeda attack on New York's World Trade Centre on 11 September 2001, and a groundswell of media/public discourse on what gets called 'Islamic extremism', and all the stories we relied upon as markers of Australian identity, lifestyle and capacity to pursue both without threat or fear, start to 


\section{CONTEMPORARY GENDER ISSUES}

sound decidedly different. Or do they?

As I have suggested, there is an historical basis in Australia to the gendered ideological construction of 'threat' as feminised (Summers, 1975, Dixson, 1999, Curthoys 2000). The private space of 'woman' came to symbolise one side of the unsettled relationship between the wild, natural, untamed 'bush', and the colonising, civilised, masculine centre of Australia. Miriam Dixson (1999, pp. 280-87) and Kay Schaffer (1988) reiterate how colonialist inscriptions of women-as-nature still affect national consciousness. A history of journalism by women (such as Daisy Bates and Ernestine Hill) venturing into this 'bush' and communing with 'nature' and its indigenous custodians remains relatively understudied, if only because it seems to fit pre-existing and enduring notions of national subjectivity and place that are formed around masculine conquest. Fast track backward, then, to more than 20 years before Schapelle, and the disappearance of baby Azaria Chamberlain from an Uluru campsite in August, 1982. Any journalist active during the Chamberlain 'Dingo Trial' of 1983 would register the discordant aspects of the Schapelle story, compared with the story of Azaria's mother, Lindy Chamberlain, tried, imprisoned for, and later exonerated of, the murder of her infant daughter. For the sake of scene-setting, both stories involved that normalised Australian activity - the holiday — but Lindy's story drew more heavily than Schapelle's upon another sacred institution, held dearly as the private spatial realm of every 'one of us': the family (Reynolds, 2005/1989, p. 2).

In a paper presented last year at Macquarie University's Lindy Chamberlain: Nation, Law, Memory symposium, Paul Reynolds (2005/1989) describes 'one of the enduring clichés of Australian, and like societies' as that of 'the family (as) the basic unit of society'. Reynolds argues that the involvement of a baby in the Lindy story 'strengthened the essential ordinariness of it all'. Crucially, though, for reportage of the Dingo Trial, the baby's body was never found. Azaria's body, or its absence, worked, as Reynolds suggests, as a symbol of 'the down-side of family life'. Private, familial discourse is exceeded by this symbolic absence, this lost innocence in female form, where blame also lies at the feet of the suspect mother. In psychoanalytic terms and, given the charge of murder levelled at Lindy, this absence of innocence, contrasts sharply at first glance with news media representations of Schapelle. Schapelle, innocent by appearance and by association with all acceptable forms of Australian identity symbolised by her boogie board and beautiful green eyes, looks back to Lindy, the mother-as-monster. The boogie board 
and the baby tell, as it turns out, a much bigger, more productive story where feminine stereotype still determines the woman to be 'monster' and the one cast as 'damsel' or 'princess' (cf Summers, 1975).

This, according to Reynolds (2005/1989, p. 3), also was the driving 'motif' in private-public, media-generated discourses of justice running wild during the Dingo Trial, where:

....it is little wonder that many who were loath to believe the Chamberlains' story, opted for a via media, that Lindy was temporarily deranged, or suffering from some form of post-natal depression. This in itself gave rise to many embellishments which seemed to have in common the mysterious world of the woman and her psychological/emotional make-up.

That 'mysterious world of the woman' is embedded in Australian popular consciousness with those equally expansive mysteries of otherness-place, landscape, religion - which unsettle audiences. It is a ripe field for the resurfacing of the grand narratives that served colonialism so well. The grand narratives of family, religion, war (or defending freedom) are produced and re-produced in big stories about women, as journalistic aspirations to objectivity obscure their historical context. It is a seductive blend. Informed by Baudrillard's analysis of all that exceeds pure production, however, it is a seduction that can be seen to have at its core a paradox linked with the conundrum of journalistic objectivity and the responsibility to accord meaning to reportage of events, which was mentioned earlier. The paradox is that this seduction draws upon weakness for its power - the weakness of Australians unsettled and anxious about their own place on the land, and in the world. ${ }^{5}$

\section{Part 4: Journalism or that other narrative:}

\section{Schapelle, Lindy, and the pull of PR}

While I do not intend to delve into the field and its attendant scholarship to any extent here, I do want to suggest that this climate of media representation contributes to the influence of public relations practice on the news media. ${ }^{6}$ This is partly because, in our private making of meaning as audiences and as journalists, we draw upon cliché, upon ideological constructions of what family is, what femininity is, what justice is and, at a more complex level, what truth is, to alleviate anxiety and story-tell our lives. This practice 


\section{CONTEMPORARY GENDER ISSUES}

fits that familiar refrain of journalism as simply story-telling, but it also alienates those who do not fit the image or identity of conventional characters in the national drama. Robert Manoff (1986, p. 228) describes it this way: narratives 'make the world make sense'. 'The sense they make, however, is conventional.' Because I am more interested in finding directions forward for journalism scholarship than PR, I am also interested in exploring how that conventional sense is subverted by anxieties over historical context (and the agents in it). The telling must involve excess, implicit and almost imperceptible registers of meaning-making, and dog-whistling, and it all exceeds the parameters of pure production. Schapelle and Lindy, then, are not just news stories about women, even if they appear to be just that. By observing their play, and comparing their textual (and contextual) similarities, we can find critical responses to questions of why Schapelle makes us sorry, but Lindy made us cruel, and Renae just makes us crop her out of photographs so we can see Michelle without her burka (Wockner, 2005).

Feminist critiques of the public sphere, such as those by Lisa McLaughlin and Ewa Ziarek, can contribute to resistance to this normalised cultural legacy of anxiety and unsettlement about women who invoke ambivalence about cultural positioning and identity. In other words, there may be a politically useful point to finding a way to theorise the contemporary culture of fear prevalent in places like Australia (Pilger, 2005; Frankel, 2004). Dominant ideological manoeuvres in Australia now tend to divide, dominate and punish any expression of difference as undeserving of compassion, or even a fair hearing. From a gender perspective, however, it has always been that way. Lindy Chamberlain's own reading, for example, of how justice was meted out to her articulates an experience of dehumanisation and castigation as a suspect mother, a not-normal woman. She told me, via her husband, Rick Creighton, how:

It is well known that money and connections can make one seem more 'deserving' of justice, male or female. But when either sex steps out of the role society proscribes for them, then society says that they don't deserve the justice another might take for granted... Lindy herself found much bias because the "crime" of murdering one's baby was so far outside the norm that people struggled to accept that anyone human could do such a thing, so she was dehumanised, which made it OK to hate her. The concept of the dingo as the culprit (every mother's night- 
mare - of not being always able to protect her young) was also far outside the understanding of most people. Both alternatives were difficult to grasp. Add to that the NT government issues and people would be more willing to believe whichever group 'helped' them understand and assimilate the story, whether the truth was being told or not (Chamberlain-Creighton \& Creighton, 2005).

Looking at the trajectory of both the Lindy and Schapelle stories, it is useful to observe how their narratives may be consonant with the charter of PR practice, rather than journalism. In a PR textbook, familiar to most tertiary educational settings in which the professional practice is taught, Robert Heath (1997, pp. 316-21) notes how all 'events occur in a context'. 'That context exhibits the key aspects of a narrative, a story. How the story is resolved determines whether the crisis goes away or leads to an issue having public policy importance.' Heath's analysis seems applicable to the way that the Australian news media drew upon historical stereotypes of femininity and subjectivity, then from Lindy's key role in the Dingo Trial, to formulate a public representation of the innocence of Schapelle:

Reporters frame news events in terms of past events that are similar and relevant. People ask themselves whether an immediate event is a continuation of a story - a narrative - they have come to accept as they think about an organisation or industry. Or they may ask whether this event is a dramatic shift in narrative - a new story. People think of events that occur in their world in narrative terms. Interpretation of the events treats them as acts by characters that have a past, present and future. Events are meaningful because they are part of a larger plot and have a plot of their own (Heath, 1997, pp. 316-17).

The equation of the feminine subject, Schapelle, in her unfortunate plight in a Denpasar jail, with an 'organisation or industry' could be construed as problematic, but it should be read in light of Baudrillard's critique of production in Western capitalist societies as already discussed. What are journalists 'producing', in their stories of Schapelle but a continuation of a familiar 'larger plot'? It is also worthwhile considering how much the Federal Government in Australia spends on advertising its draconian 'anti-terrorism' legislation, when the historical moment of such stories gaining saturation coverage is pinpointed. The ideological underpinning may be: this too, could happen to 


\section{CONTEMPORARY GENDER ISSUES}

you, young as (you think) you are, innocent as you are, quintessentially and attractively Australian as you are. An already unsettled audience, ambivalent about what kind of woman deserves its sympathy, and who is to blame when sacred aspects of national identity are challenged, is prone to its own crisis response. This has been, for the past five years, at least, in Australia, to allow the Government to police the boundaries of nationality, inclusion and socioeconomic contribution. The news media's role could be observed as facilitating this response because, as Lindy Chamberlain-Creighton says, it helps people understand and assimilate the story, 'whether the truth was being told or not'.

\section{Conclusion}

I have made some speculative observations here about more complicated aspects of journalism's position in relation to an unsettled Australian postcolonial milieu, but these observations require a much longer critical project than was possible in this article. Schapelle and Lindy, as big stories about women, have nevertheless provided a start to studying how feminised apprehensions of culture and identity forming a nation's history can certainly still in-form notions of justice in news media production. Some speculative observations of gender representation in two long-running news stories signal my intention beyond this article to continue a discussion of the concerted ideological constructions of a whole cluster of motifs of culture and identity. The cluster includes race, ethnicity, class, religion, as each is mobilised in the story of contemporary Australia. And each compels journalistic practice with (at least) an aspiration to principled public interest by offering meaning, via historical context, to its reportage.

I have started a feminist (re)reading of Baudrillard which draws on existing scholarship in order to find sound approaches, via cultural studies, to a critical understanding of why particular feminine representations are draped over all the most expensive things we are sold, and told, about ourselves and cultures outside Australia's national borders. The point of this approach is to argue that an account of the seductive play of appearances as observed by Baudrillard, and applied to stories about women, is especially useful in the unsettled postcolonial milieu of Australia. Baudrillard's identification of masculine privilege against feminised seduction has its basis in historical context. For journalism practice (and journalism scholarship) Baudrillard's insistence on the illusory basis of this division holds much promise. Its sim- 
plest application may be looking behind appearances to weakness, in a crucial time for speaking truth to power.

\section{Notes}

1 Feminist critic Margaretta Jolly chronicles use of first-person narrative by interdisciplinary feminist scholars as a way of interrogating the notion of objectivity. She states '...the job of an academic is not to argue until we arrive at some final objectivity, but to find ways of understanding and living with our differences' (2005, p. 214).

2 Poster 162.

3 Grace also reminds us of Baudrillard's observation that there is no reason beyond historical context and cultural circumstance for associating femininity with the 'seductive' and masculinity with the 'productive'.

4 Baudrillard's "'of the play of appearances shift(ting) the site of analysis from one solely focused on semiotics...' also should be noted.

5 I refer always to non-indigenous Australians in such references. Indigenous peoples as sovereign presence have suffered by these anxieties rather than from them.

$6 \mathrm{My}$ intention is not to analyse or critique PR scholarship. Martinson, White, Greve, Storr and Manoff (2004), and Knightley offer salient illustrations of some of journalism's most important concerns. One or two of these are my concern here.

\section{References}

ABC Radio National. (2005). Women who transgress. Background Briefing. (Retrieved March, 2006). www.abc.net.au/rn/talks/bbing/stories/s1418395.htm

Bates, D. (1947). The passing of the Aborigines: A lifetime spent among the natives of Australia. (2nd Ed.). London: Murray.

Baudrillard, J. (1979). On seduction. In Poster, M. (Ed.), (1998). Jean Baudrillard: Selected writings (pp.149-165). Cambridge: Polity.

Chamberlain-Creighton, L., and Creighton, R. (2005). Personal communication with author.

Curthoys, A. (2000). Mythologies. In R.Nile (Ed.), The Australian legend and its discontents (pp.1-41). Brisbane: UQP-API Network.

Dixson, M. (1999). The real Matilda: Woman and identity in Australia 1788 to the present (4th Ed.) (pp.280-287). Sydney: UNSW Press.

Frankel, B. (2004). Zombies, Lilliputians and sadists: The power of the living dead and the future of Australia. Fremantle, WA: Curtin University Books.

Gelder, K., and Jacobs, J. (1998). Uncanny Australia: Sacredness and identity in a postcolonial nation. Melbourne: Melbourne University Press.

Goodwin, K. (2005, February 23). Realistically, it's better to be naïve: communication theory may be at the end of its tether. The Australian, pp. 36-37.

Grace, V. (2000). Baudrillard's challenge: A feminist reading. New York: Routledge.

Greve, F. (2005). Journalism in the age of pseudoreporting. Nieman Reports Summer, pp. 11-13. 


\section{CONTEMPORARY GENDER ISSUES}

Heath, R. (1997). Strategic issues management: Organizations and public policy challenges (pp.316-321). London: Sage.

Hill, E. (1937). The great Australian loneliness. London: Jarrolds.

Jolly, M. (2005). Speaking personally, academically. Feminist Theory, 6 (2), pp. 213-220.

Knightley, P. (2005). Restoring citizen's respect for journalism: we are not without power. (Retrieved August 2005) http://webdiary.smh.com.au/archives/ margo_kingston/001389.html

Leslie denies wearing burqua to win favour. ABC Online (Retrieved September, 2005) www.abc.net.au

Little, J. (1997). 'Unsinkable' big things: Spectacle, race and class through Elvis, Titanic, OJ, and sumo. Overland, 148, pp. 12-15.

Little, J. (1999). The critique of race: Critical migration and memory in American and Australian cultural representations. Unpublished doctoral dissertation. Brisbane: School of English, Media Studies, and Art History, University of Queensland.

Lumby, C. (1997). Bad girls: The media, sex and feminism in the 90s. Sydney: Allen and Unwin.

Manne, R. (March, 2006). Little America: How John Howard has changed Australia. The Monthly, pp. 20-33.

Manoff, R. (2004). Democratic journalism and the republican subject: Or, the real American dream and what journalism educators can do about it. Zoned for debate. New York: Department of Journalism, New York University. (Retrieved August 2004). http://journalism.nyu.edu/pubzone/debate/forum.1.essay.manoff.html

Manoff, R. (1986). Writing the news (by telling the 'story'). In Manoff, R., Schudson, M. (Eds), Reading the news. (pp. 197-229) New York: Pantheon.

Marr, D., and Wilkinson, M. (2003). Dark victory. Sydney: Allen and Unwin.

Martinson, D.L. (2006, January 2-9). The media, the war and 'truth'. America, pp. 10-13.

Morgan, R. (2005, June 4). Majority of Australians believe Schapelle Corby is not guilty, although a large number undecided. Roy Morgan Research.Poll Finding No.3866. (Retrieved August 2005). www.roymorgan.com/news/polls/2005/3866/

McLaughlin, L. (1998). Gender, privacy and publicity in 'media event space'. In Carter, C., Branston, G., and Allan, S. (Eds.), News, gender and power (pp. 71-90). London: Routledge.

Nine MSN (2005). The Corby trial: Have your say (Retrieved October 2005) http://news.ninemsn.com.au/article.aspx?id=63349.

Schapelle's nightmare: the untold story. (2005, May). Nine Televison.

Pilger, J. (2005, February 7). Fear and silence in Australia. The New Statesman. (Retrieved March 2006) www.newstatesman.com/200502070017

Reynolds, P. (1989, August). The Azaria Chamberlain case: Reflections on Australian identity. Paper presented at the Lindy Chamberlain: Nation, law, memory symposium. Sydney: Macquarie University. Robert Menzies Centre for Australian Studies, Institute of Commonwealth Studies. Working Paper No. 47.

144 PACIFIC JOURNALISM REVIEW 12 (1) 2006 
Schaffer, Kay. (1988). Women and the bush: Forces of desire in the Australian cultural tradition. Cambridge: Cambridge University Press.

Seal, G. (2005). Personal communication with author.

Seal, G. (2005, August). Lindy, Schapelle and the media charivari. Paper presented at the Lindy Chamberlain: Nation, law, memory symposium. Sydney: Macquarie University.

Stoff, R. (2005, July-August). Trust us. St. Louis Journalism Review, p.11 \& p.27.

Summers, A. (1975). Damned whores and God's police: The colonization of women in Australia. Ringwood, Vic: Penguin.

White, A. (2005). Truth, honesty and spin. Democratization (125), pp. 651-667.

Wockner, C. (2005, October 29). Model and mule share the spotlight. The CourierMail, p. 1.

Ziarek, E. (2005). The abstract soul of the commodity and the monstrous body of the sphinx: Commodification, aesthetics and the impasses of social construction. Differences, 16 (2). pp. 88-115.

Dr Janine Little is a lecturer in print journalism at the Toowoomba Campus of the University of Southern Queensland. She has worked in the Australian and British print media and has a PhD in English/cultural studies. littlej@usq.edu.au

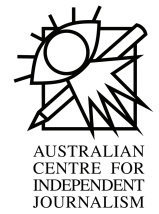

\section{‘PUBLIC RIGHT TO KNOW’ SPECIAL EDITIONS}

The Australian Centre for Independent Journalism (ACIJ) is a Journalism Research Centre attached to the University of Technology, Sydney. The ACIJ is fully committed to the principle that democratic societies require independent, critical and investigative journalism of the highest standard. Each year the ACIJ hosts the Public Right To Know conference. It brings journalists, academics and students together to discuss media issues and the public right to know. Papers from the 2002 and 2003 conferences have been published in the UTS Law Journal and Pacific Journalism Review respectively. The 2004 papers were published in Australian Journalism Review.

Copies are available through the AClJ.

Please email acij@uts.edu.au or visit the website at www.acij.uts.edu.au

University of Technology, 755 Harris Street, Ultimo NSW.

PO Box 123, Broadway NSW 2007, Sydney, Australia

Ph: +61 295142488 Fax: +61292812976 email: acij@uts.edu.au 
Copyright of Pacific Journalism Review is the property of Auckland University of Technology and its content may not be copied or emailed to multiple sites or posted to a listserv without the copyright holder's express written permission. However, users may print, download, or email articles for individual use. http://www.aut.ac.nz/depts/commstud/journ/pjrsubs.shtml 